\title{
Physicochemical Profiling of Different Released and Improved Desert and Cooking Banana Varieties
}

\author{
Mulate Zerihun, Masresha Minuye \\ Melkassa Agriculture Research Center (Food Science and Nutrition), EIAR, Addis Ababa, Ethiopia \\ Email address: \\ mulatezerihun@yahoo.com (M. Zerihun), masreshaminuye@gmail.com (M. Minuye)

\section{To cite this article:} \\ Mulate Zerihun, Masresha Minuye. Physicochemical Profiling of Different Released and Improved Desert and Cooking Banana Varieties. \\ Bioprocess Engineering. Vol. 3, No. 2, 2019, pp. 12-21. doi: 10.11648/j.be.20190302.13
}

Received: December 7, 2019; Accepted: December 31, 2019; Published: January 8, 2020

\begin{abstract}
Banana (Musa spp.) is an important ingredient of several dishes and its nutritional and other biochemical composition of released and improved desert and cooking types are yet to be scientifically studied fully. In the present study, the most popularly cultivated species of cooking and desert type banana in Ethiopia selected. The objective of this study was to determine their physicochemical profiling and nutritional quality of desert and cooking banana varieties. The chemical composition and some physicochemical characteristics of the fresh fruit and flour obtained from seventeen different banana varieties are presented. A randomized complete design with three replications was used. Length, Width, Peel and pulp thickness, Pulp to peel ratio, total soluble solids, $\mathrm{pH}$, titratable acidity, ash and moisture of desert banana (Fresh) and mineral contents are the most important parameters to evaluate the quality of banana including potassium. The different varieties affected the fruit physical characteristics significantly $(\mathrm{P} \leq 0.05)$. The Cardaba varieties fruit was found to be the heaviest and the longest. The Kitawira and Nijiru varieties had the smallest, shortest and thinnest fruit. The Cardaba, Nijiru, Matoke, and Kitawira contained more pulp weight than peel weight. Most fruit chemical quality parameters were significantly $(\mathrm{P} \leq 0.05)$ affected by the varieties. The chemical composition of the flour also varied according to the variety and types of banana. Among others, the Cardaba variety was found to have high fruit weight, juice volume, total soluble solids, dry matter, and low total titratable acidity. Banana flour is rich in potassium varied from 246.288 to $375.949 \mathrm{mg} / 100 \mathrm{~g}$ according to the variety. The range obtained were $41.200-89.132 \mathrm{mg} / 100 \mathrm{~g}$ phosphorus, $0.705-19.352 \mathrm{mg} / 100 \mathrm{~g}$ sodium, 2.497 - 3.359\% ash, and 71.529 76. 564\% moisture. The sensory analysis of desert banana type was evaluated. Thus, there was no significant difference between varieties at $\mathrm{P} \leq 0.05$ and sensorial acceptability in most varieties. The current study revealed the variations of biochemical compositions of desert and cooking banana varieties. This will be useful for the exploitation of these crops to obtain and formulate the value-added products. These varieties are recommended for different food product development by food processors in Ethiopia.
\end{abstract}

Keywords: Banana, Desert, Cooking, Mineral, Physical, Chemical, Sensory Quality

\section{Introduction}

Banana is one of the most widely distributed and consumed fruit in the tropical and subtropical countries of the world [1]. Banana is the common name of herbaceous plants of the genus Musa and for the fruit they produce. Banana plants are monocotyledons, perennial and important crops in the tropical and subtropical world region [2]. They include desert banana, plantain, and cooking banana. Plantain and cooking banana (Musa spp. $\mathrm{AAB}$ and $\mathrm{ABB}$ groups) is cultivated mainly as a carbohydrate staple in many developing countries, especially in Africa [3]. According to the Food and Agriculture Organization of the United Nations statistical division (FAOSTAT 2013) [4], 106,714,205 tonnes and $37,877,805$ tonnes of banana and plantains were produced worldwide, with about $16 \%$ banana and $72 \%$ plantain respectively produced in Africa. Production levels of plantains and cooking banana are however affected by several factors [5].

In Ethiopia, banana production is concentrated in the southern region of Ethiopia and the major produce comes from small scale growers. The average banana production in between 1961 and 2011 production year varied from 60,000 tin 1961 to 270,000 tin 2011. Its production and utilization 
have many technical, economic and social problems that attract research attention in order to exploit its immense suitability potential [6, 7]. The Ethiopian Institute of Agricultural Research (EIAR) introduced some banana germplasms and the collection of desert and local cooking banana clones. These materials were evaluated by Werer, Melkassa, and Jimma Agricultural Research Centres. Among these, four cooking type banana varieties were released in 2006 by Melkassa Agricultural Research Centre based on their better agronomic performance as well as increased disease resistance. The four cooking types banana varieties released were Cardaba, Kitawira, Matoke, and Nijiru.

New economic strategy to increase utilization of banana includes the production of banana flour when the fruit is unripe and to incorporate the flour into various innovative products such as slowly digestible cookies [8], high-fiber bread [9] and edible films [10]. The development of new products is a strategic area in the food industry. Considering the nutritional aspects of banana, it is one of the world's leading food crops with rich sources of minerals, vitamins, carbohydrates, flavonoids and phenolic compounds [11] and it is one of the easily accessible economic fruit crops to common people. It can be consumed as cooked as well as in uncooked forms [12]. Consumers demand foods mainly of two reasons, one in deal with the traditional nutritional aspects of foods, whereas the second feature is that the additional health benefits accepted from its regular ingestion and such kinds of food products are called nutraceutical foods $[3,12]$. In Ethiopia, the bulk of banana produced in the country is utilized in domestic market as fresh fruit but for a few processed products like chips. There is immense potential for processing banana into several value-added products like dehydrated ripe banana jam, jelly, fruit bar, wine, vinegar, puree, baby food and pickle which can fetch profit both in the domestic as well as in the foreign market [13].

The production and utilization of these varieties have been consistently increasing since 2006 in Ethiopia. Yet the physicochemical and mineral proportion of the various varieties are relatively not well known. The existing potential could only benefit the nation if it could be fully exploited through the export of processed and fresh banana products, including chips. As was mentioned earlier, all improvement works conducted in Ethiopia, particularly, on banana, focused mainly on selecting promising varieties in terms of high yield, cold tolerance, disease, and insect resistance without giving much attention to post-harvest and processing quality evaluation [7, 13, 14]. Moreover, the improvement efforts would be complete and sustainable, if the breeder materials could be tested for their physicochemical and mineral quality in different value-added food products and dried products [13, 15]. However, very limited scientific information exists on physicochemical, mineral and processing of cooking banana including desert and plantains. Several cultivars of plantain, desert and cooking type bananas have been developing which are disease and pest resistant, high yielding and good postharvest qualities that are being tested and or distributed to farmers in plantain growing areas. The need to characterize these new and improved varieties to assess their suitability in various food systems and their eventual adoption in various diets is very important. Therefore, the present work was undertaken to study the nutritional and mineral compositions of desert and cooking banana type of different varieties. The study emphasizes the nutritional and mineral compositions characterization of these varieties and evaluation of their sensory characteristics data obtained in this study.

\section{Materials and Methods}

\subsection{Materials}

Four locally released cooking type banana varieties by Melkassa Agricultural Research Centre in 2006 (MoARD 2006) namely Cardaba (ABB, Saba banana/2006MARC/EIAR), Kitawira (AAB, 2006-MARC/EIAR), Matoke (AAB, 2006MARC/EIAR), and Nijiru (AAB, 2006MARC/EIAR), nine desert type variety and pipe-line trail bananas were used for this experiment. These fruits were collected from Melkassa agricultural research center horticulture research experimental field. From this experimental, bunches were examined about 3 months before harvest in order to make propping as per the requirement of the plant. Finally, matured fingers were harvested using visual banana maturity indices, hanging bunch and particularly by individual fingers angularity. The harvested bunches were carefully transported to Melkassa agricultural research center food science and nutrition research laboratory. Freshly harvested bunches were used to conduct the whole experiments and the cooking banana type varieties processed for further analysis.

\subsubsection{Preparation of Sample}

The harvesting of bunches was done three times depending on the availability of fruits that reached the required stage of maturity. This means that each variety had 15 bunches for analysis. The harvested bunches were stored at ambient conditions $\left(28-31^{\circ} \mathrm{C}, 56-62 \% \mathrm{RH}\right)$ on a wooden platform. Twenty fruits at the proximal, midsection and distal hand position from the five bunches were randomly selected, washed and peeled. The peeled fruits were cut into slices of $0.5 \mathrm{~cm}$ thick disc using a vegetable slicer. The slices were then chopped, thoroughly mixed thoroughly with a Hobart cutter. The fresh ripe and unripe bananas were peeled, cut into thin slices and dried in an electric oven at $60^{\circ} \mathrm{C}$ for $12 \mathrm{~h}$. Dried samples were ground, sieved and stored at room temperature $\left(25^{\circ} \mathrm{C} \pm 2^{\circ} \mathrm{C}\right)$ in airtight containers and the powdered sample was used for further chemical compositions analysis.

\subsubsection{Experimental Sampling and Design}

A composite sample of healthy, clean fingers at the matured green stage was prepared for each variety from the second and a third hand of the three bunches. Furthermore, the composite samples from each variety were sub-divided 
into three sets and arranged in a randomized complete block design (RCBD) with three replications. From each sample set, considering the fresh sample in the determination of fruit peel, pulp weight, juice volume, the total soluble solids, and total titratable acidity. From each sample set ten sample fruit were randomly taken and arranged for fruit physical, chemical and mineral quality parameter determinations.

\subsection{Physical Quality Analysis}

Fifteen fruit from each set was used for the analysis of physical parameters. All fruit physical quality evaluations were done according to Dadzie and Orchard (1997) [16]. Each finger girth and length were measured by tape meter. The volume was measured by water replacement in a waterfilled measuring cylinder. Fruit peel and pulp weight were measured using a beam balance. Bunch weight the average weight of the bunch was determined on the whole bunch using a Salter and Scale $( \pm 0.1 \mathrm{~g})$. Fruit length Measurements were done on the outermost curvatures of the fruit. An Inextensible measuring tape was used. The fruit length was measured at the proximal, midsection and distal hand positions of the plantain and cooking banana samples. Fruit width Measurements were done at the widest midpoint of the fruit. An Inextensible measuring tape was used. The fruit width was measured at the proximal, midsection and distal hand positions of the plantain and cooking banana samples. Furthermore, the pulp to peel ratio was calculated from collected data. Pulp and peel weight were determined after fingers have been hand-peeled and both peel and pulp were weighed separately using an analytical balance. To calculate pulp to peel ratio, the weight of pulp and peel was used and expressed as a ratio of pulp weight divided by the peel weight. To measure peel and pulp thickness, the fruit was transversely cut at the midpoint and hand peeled. Then, the peel and pulp thickness were measured with a digital microcaliper. In addition to the calculated pulp to peel ratio from the measured values, the pulp thickness was used as easy to peel indices. The initial pulp mass, the firmness, the dry matter content and the moisture content of the representative sample was measured $[13,17]$.

\subsection{Chemical Composition Analysis}

Among the chemical properties, total soluble solids (TSS), dry matter (DM), $\mathrm{pH}$ and total titratable acidity (TA) were measured according to INIBAP technical guidelines [18, 19]. TSS was measured by blending $30 \mathrm{~g}$ of pulp tissue that was taken from the transverse section of the fruit in $90 \mathrm{~m} 1$ distilled water for $2 \mathrm{~min}$ in a blender and the slurry was filtered through filter paper. A single drop of a filtrate was placed on a prism of calibrated digital handheld refractometer (Misco ${ }^{\circledR}$, USA) with a degree Brix range of $0-32 \%$ and resolutions of $0.2^{\circ}$ Brix at $20^{\circ} \mathrm{C}$ with distilled water. The $\mathrm{pH}$ value of the filtrate was determined using a $\mathrm{pH}$ meter (ELE International, U.K). The $\mathrm{pH}$ of the sample was determined by methods given by Berwald et al. [19]. $10 \mathrm{~g}$ of sample was weighed and it was macerated with $100 \mathrm{~mL}$ of deionized water. It was thoroughly mixed and the mixture was allowed to stand for 30 minutes. The supernatant was collected by centrifugation at $7863 \mathrm{~g}$ for $15 \mathrm{~min}$ using refrigerated centrifuge and the supernatant was decanted and determined the $\mathrm{pH}$. The titrable acidity (TA) of filtrate was measured by titrating against sodium hydroxide to the phenolphthalein endpoint and calculation of the acid present as malic acid [20]. The flour sample was analyzed for proximate composition according to [20] and was determined in triplicates. Moisture content was determined by weighing $5 \mathrm{~g}$ of the sample and drying in an oven at $105^{\circ} \mathrm{C}$ to constant weight. Ash content was determined by incineration of $5 \mathrm{~g}$ of the sample in a muffle furnace at $525^{\circ} \mathrm{C}$ and the weight of the ash was calculated by difference [21].

\subsection{Mineral Analysis}

The first step involved in the elimination of the inorganic materials through the procedure of wet ashing. About $0.5 \mathrm{~g}$ of the sample was weighed into a $250 \mathrm{ml}$ beaker. Twenty-five $\mathrm{ml}$ $(25 \mathrm{ml})$ of concentrated nitric acid was added and beaker covered with a watch glass. The sample was digested with great care on a hot plate in a fume chamber until the solution was pale yellow. The solution was cooled and $1 \mathrm{ml}$ perchloric acid $(70 \% \mathrm{HClO} 4)$ added. The digestion was continued until the solution was colorless or nearly so (the evaluation of dense white fumes indicates the removal of nitric acid). When the digestion was completed, the solution was cooled slightly and $30 \mathrm{ml}$ of distilled water added. The mixture was brought to boil for about $10 \mathrm{~min}$ and filtered hot into a 100 $\mathrm{ml}$ volumetric flask using a Whatman No. 4 filter paper. The solution was then made to the mark with distilled water [22].

Determination of $\mathrm{Na}$ and $\mathrm{K}$ Two (2) $\mathrm{ml}$ of the digest was used in the determination of sodium and Potassium using the flame photometric method [23, 24]. The photometer (Jenway, United Kingdom) model PF P7 with methane gas was used. Phosphorus determination Two (2) $\mathrm{ml}$ aliquot of the digest was reacted with $5.0 \mathrm{ml}$ molybdic acid (The molybdic acid was prepared by dissolving $25 \mathrm{ml}$ of ammonium molybdate in $300 \mathrm{ml}$ distilled water; with $75 \mathrm{ml}$ of concentrated sulphuric acid in $125 \mathrm{ml}$ of water to get 0.51 of molybdic acid) $1 \mathrm{ml}$ each of $1 \%$ hydroquinone and $20 \%$ sodium sulfite was added in that sequence, and the solution was made up to $100 \mathrm{ml}$ and allowed to stand for $30 \mathrm{~min}$ in order to allow the color to stabilize after which the absorption was measured at $680 \mathrm{~nm}$. A standard curve colorimetric reading versus concentration of phosphorus using portions of standard phosphorus solutions (1, 2 and $3 \mathrm{ml}$ ) subjected to reactions with molybdic acid, hydroquinone, and sodium sulphate solutions was drawn. All readings were corrected by the reading of a blank to eliminate the effect of any color produced by the reagents. The phosphorus content was expressed as $\mathrm{mg} / 100 \mathrm{~g}$ of sample.

\subsection{Sensory Evaluation}

A total of 21 male and female panelists were used. Each panelist was first briefed with the important sensory 
evaluation conceptual knowledge. Then, each panelist was presented with a score sheet that was specifically designed for this experiment, a pen, pure water for mouth rinsing and fresh fruit samples. Each panelist received and evaluated the same amount of duplicate coded sample in a controlled sensory evaluation laboratory with separate boxes for each panelist. The samples were evaluated on the basis of their texture, taste, color, peel conditions and overall acceptability. Furthermore, all panelists scored the samples for each quality feature using a hedonic scoring scale of 1 to 5 on the provided evaluation sheet.

\subsection{Statistical Analysis}

Experiments were carried out in three replicates and samples from each variety were sub-divided into three categories. One-way ANOVA was carried out to examine whether the difference in the chemical components present in the different samples was significant or not. Comparisons between the sample means were done using the least significant differences (USD) at 5\% significance level.

\section{Results and Discussion}

\subsection{Physical and Chemical Characteristics of Desert and Trial Banana Varieties}

The physical and chemical characteristics of the desert and trial banana cultivars are summarized in Tables 1 and 2 . Variety had a significant $(\mathrm{P} \leq 0.001)$ effects on most of the fruit physical quality parameters (Table 1 ). However, the $\mathrm{P}^{\mathrm{H}}$ value of the fruit was showed significant $(\mathrm{P} \leq 0.05)$ difference was observed between the fruit sample $\mathrm{pH}$ value of the varieties were recorded.

Table 1. Physicochemical quality data result for released desert banana varieties.

\begin{tabular}{|c|c|c|c|c|c|c|}
\hline Varieties & PH & TSS & $\mathbf{T A}$ & TSS/TA & Moisture & Ash \\
\hline Butuza & $4.9067^{\mathrm{a}}$ & $22.667^{\mathrm{a}}$ & $5.5657^{\mathrm{b}}$ & $4.0733^{\mathrm{b}}$ & $72.075^{\mathrm{c}}$ & $2.8817^{\mathrm{a}}$ \\
\hline Dwarfe Cav & $4.8033^{\mathrm{ab}}$ & $22.800^{\mathrm{a}}$ & $4.2727^{c}$ & $5.3400^{\mathrm{a}}$ & $72.169^{c}$ & $2.8537^{\mathrm{a}}$ \\
\hline Williams-1 & $4.7970^{\mathrm{ab}}$ & $20.000^{\mathrm{b}}$ & $6.1247^{\mathrm{a}}$ & $3.2700^{\mathrm{c}}$ & $74.567^{\mathrm{a}}$ & $2.7110^{\mathrm{a}}$ \\
\hline Grande Nai & $4.6733^{\mathrm{b}}$ & $22.350^{\mathrm{a}}$ & $4.2320^{c}$ & $5.2893^{\mathrm{a}}$ & $73.635^{\mathrm{b}}$ & $2.2213^{\mathrm{b}}$ \\
\hline LSD & 0.1350 & 0.7796 & 0.2884 & 0.3707 & 0.5373 & 0.2364 \\
\hline F-Calcu & 5.32 & 30.3 & 115 & 78.0 & 53.5 & 17.9 \\
\hline Significance & $* *$ & $* * *$ & $* * *$ & $* * *$ & $* * *$ & $* * *$ \\
\hline
\end{tabular}

$\mathrm{ns}, * * * * * *$ non-significant or significant at $\mathrm{P} \leq 0.05, \mathrm{P} \leq 0.01$ or 0.001 , respectively; means with the same letter within columns were not significantly different at $\mathrm{P} \leq 0.05$.

The physical quality characteristics of the pipeline banana varieties are presented in Table 2 . The fruit length of Chinese Dw and Ambowha Se were found to be 185.91 and 185.86 respectively. The pipeline variety had a significant $(\mathrm{P} \leq 0.001)$ effects on most of the fruit physical quality parameters (Table 2).

Table 2. Physical characteristics of Pipeline varieties of banana.

\begin{tabular}{|c|c|c|c|c|}
\hline Varieties & Length & Width & Peel Thickness & Peel/Pulp Ratio \\
\hline Chinese Dw & $185.91^{\mathrm{a}}$ & $45.157^{\mathrm{a}}$ & $3.3220^{\mathrm{b}}$ & $2.4633^{c}$ \\
\hline Ambowha Se & $185.86^{\mathrm{a}}$ & $39.067^{\mathrm{c}}$ & $3.1273^{\mathrm{b}}$ & $2.0913^{\mathrm{d}}$ \\
\hline Paracido-E & $159.54^{\mathrm{b}}$ & $39.860^{\mathrm{bc}}$ & $4.2033^{\mathrm{a}}$ & $2.3827^{\mathrm{cd}}$ \\
\hline Ambo-2 & $150.88^{\mathrm{bc}}$ & $40.443^{\mathrm{bc}}$ & $3.0287^{\mathrm{b}}$ & $2.8390^{\mathrm{b}}$ \\
\hline Williams-H & $150.56^{\mathrm{bc}}$ & $42.911^{\mathrm{ab}}$ & $2.3067^{\mathrm{c}}$ & $2.9960^{\mathrm{ab}}$ \\
\hline Lady Finge & $150.21^{\mathrm{bc}}$ & $38.107^{\mathrm{c}}$ & $4.1000^{\mathrm{a}}$ & $2.2483^{\mathrm{cd}}$ \\
\hline Dinke-2 & $150.09^{\mathrm{bc}}$ & $38.379^{c}$ & $3.2000^{\mathrm{b}}$ & $2.2117^{\mathrm{cd}}$ \\
\hline Ambo-3 & $138.89^{c}$ & $38.163^{\mathrm{c}}$ & $3.1760^{\mathrm{b}}$ & $3.1873^{\mathrm{a}}$ \\
\hline LSD & 13.600 & 3.3498 & 0.5362 & 0.3324 \\
\hline F-Calcu & 14.0 & 4.93 & 14.8 & 12.7 \\
\hline $\mathrm{CV}$ & 4.93 & 4.88 & 9.85 & 7.47 \\
\hline Significance & $* * *$ & $* * *$ & $* * *$ & $* * *$ \\
\hline
\end{tabular}

ns, ***,***non-significant or significant at $\mathrm{P} \leq 0.05, \mathrm{P} \leq 0.01$ or 0.001 , respectively; means with the same letter within columns were not significantly different at $\mathrm{P} \leq 0.05$.

The result of the physic-chemical composition of the different pipe-line banana varieties is given in Table 3 . The $\mathrm{P}^{\mathrm{H}}$ value was ranged from 4.69 to 5.20 in Ambowha Se and
Dinke-2 varieties respectively. The total soluble solid values were showed highly significant difference between pipeline banana varieties. The Williams-h variety was showed the 
highest value and the Ambo-3 variety was showed the lowest value compared to other pipe-line varieties. The titrable acidity values were obtained highly significant difference between pipeline banana varieties. The Ladyfinger variety was showed the highest variety and Dinkee- 2 variety was showed the lowest value compared with the pipeline varieties.

Table 3. Physic-chemical parameters of pipe-line banana verities.

\begin{tabular}{|c|c|c|c|c|c|c|}
\hline Varieties & PH & TSS & $\mathbf{T A}$ & TSS/TA & MO & Ash \\
\hline Dinke-2 & $5.2000^{\mathrm{a}}$ & $23.700^{\mathrm{abc}}$ & $3.7103^{\mathrm{c}}$ & $6.3970^{\mathrm{a}}$ & $72.582^{\mathrm{e}}$ & $3.1210^{\mathrm{ab}}$ \\
\hline Dinke-1 & $5.1977^{\mathrm{a}}$ & $22.133^{\mathrm{cd}}$ & $4.9220^{\mathrm{b}}$ & $4.4983^{\mathrm{cd}}$ & $73.355^{\mathrm{d}}$ & $2.7710^{c}$ \\
\hline Ambo-2 & $5.1633^{a b}$ & $22.300^{\mathrm{bcd}}$ & $3.7300^{c}$ & $5.9837^{\mathrm{a}}$ & $75.543^{b}$ & $3.0450^{\mathrm{b}}$ \\
\hline Ambo-3 & $5.0170^{\mathrm{abc}}$ & $20.000^{\mathrm{e}}$ & $4.8913^{b}$ & $4.0957^{\mathrm{d}}$ & $76.564^{\mathrm{a}}$ & $3.3587^{\mathrm{a}}$ \\
\hline chinese dw & $4.8540^{\mathrm{bcd}}$ & $21.333^{\mathrm{de}}$ & $3.9803^{c}$ & $5.3817^{\mathrm{b}}$ & $74.823^{c}$ & $2.8747^{\mathrm{bc}}$ \\
\hline williams-h & $4.8140^{\mathrm{cd}}$ & $24.467^{\mathrm{a}}$ & $5.0003^{b}$ & $4.8947^{\mathrm{c}}$ & $71.529^{f}$ & $2.8687^{\mathrm{bc}}$ \\
\hline Paracido-e & $4.7873^{\mathrm{cd}}$ & $21.000^{\mathrm{de}}$ & $5.1383^{b}$ & $4.0873^{\mathrm{d}}$ & $71.745^{f}$ & $2.497^{\mathrm{d}}$ \\
\hline Lady finge & $4.7177^{\mathrm{cd}}$ & $23.967^{\mathrm{ab}}$ & $5.9407^{\mathrm{a}}$ & $4.0360^{\mathrm{d}}$ & $71.651^{\mathrm{f}}$ & $2.6487^{\mathrm{cd}}$ \\
\hline Ambowha se & $4.6903^{d}$ & $20.333^{\mathrm{e}}$ & $5.9473^{\mathrm{a}}$ & $3.4233^{\mathrm{e}}$ & $75.707^{\mathrm{b}}$ & $3.3107^{\mathrm{a}}$ \\
\hline LSD & 0.3165 & 1.6959 & 0.3375 & 0.4826 & 0.6970 & 0.2601 \\
\hline F-calcu & 3.83 & 8.06 & 56.2 & 37.2 & 70.4 & 11.0 \\
\hline $\mathrm{CV}$ & 3.74 & 4.47 & 4.09 & 5.92 & 0.55 & 5.15 \\
\hline P -Value & 0.0085 & 0.0001 & 0.0000 & 0.0000 & 0.0000 & 0.0000 \\
\hline
\end{tabular}

$\mathrm{ns}, * * *, * * *$ non-significant or significant at $\mathrm{P} \leq 0.05, \mathrm{P} \leq 0.01$ or 0.001 , respectively; means with the same letter within columns were not significantly different at $\mathrm{P} \leq 0.05$. TSS total soluble solids; TA titrable acidity; MO moisture.

The moisture content was ranged from $71.529 \%$ to $76.564 \%$ in Williams-h and Ambo-3 varieties respectively. The bananas generally contain $60 \%-68.6 \%$ of moisture as they ripen; it gradually increases from $68.6 \%-78.1 \%$ [25]. An increase in the moisture content during ripening might be due to carbohydrate breakdown, softening the tissue texture and osmotic transfer from the peel to pulp [26]. The ash content was ranged from $2.497 \%$ to $3.359 \%$ in the Paracido-e variety sample and Ambo-3 variety respectively. There were varied changes in the mineral composition of bananas varieties and the ash content also varied from one variety to another variety, it may be genetically difference. Khawas et al [25] reported that ash content of banana fruits shows variations, which may be due to the differential absorption capacity of minerals at different stages and varieties of different fruit.

\subsection{Physical and Proximate Composition of Cooking Banana Type}

The result of the physical and proximate composition of the four released and improved varieties of cooking bananas are given in Tables 4 and 5 .

Table 4. Physical quality characteristics of the four cooking banana varieties.

\begin{tabular}{|c|c|c|c|c|c|c|c|}
\hline Varties & FW (g) & PLW (g) & PPW (g) & FL (cm) & PPR & JV (mL) & TSS (\%) \\
\hline Cardaba & $178 \mathrm{a}$ & $54 a$ & $124 \mathrm{a}$ & $16 \mathrm{a}$ & $2.30 \mathrm{a}$ & $194 a$ & $1.70 \mathrm{a}$ \\
\hline Kitawira & $73 c$ & $30 \mathrm{c}$ & $43 c$ & $12 b$ & $1.43 \mathrm{~b}$ & $65 c$ & $1.60 \mathrm{a}$ \\
\hline Matoka & $119 b$ & $48 b$ & $71 \mathrm{~b}$ & $17 \mathrm{a}$ & $1.48 \mathrm{~b}$ & $119 b$ & $1.60 \mathrm{a}$ \\
\hline Nijeru & $69 \mathrm{c}$ & $24 c$ & $45 c$ & $13 b$ & $1.88 \mathrm{~b}$ & $74 c$ & $1.50 \mathrm{a}$ \\
\hline Mean & 109.75 & 39.00 & 70.75 & 14.50 & $1.77 \mathrm{~b}$ & 113.00 & 1.60 \\
\hline $\mathrm{CV}$ & 6.11 & 4.77 & 4.56 & 3.28 & 4.42 & 5.93 & 2.90 \\
\hline Significance & $* * *$ & $* *$ & $* * *$ & $* *$ & $* *$ & $* * *$ & ns \\
\hline
\end{tabular}

$\mathrm{ns}, * * *, * * *$ non-significant or significant at $\mathrm{P} \leq 0.05, \mathrm{P} \leq 0.01$ or 0.001 , respectively; means with the same letter within columns were not significantly different at $\mathrm{P} \leq 0.05$.

FW fruit weight; PLW peel weight; PPW pulp weight; FL fruit length; JV juice volume; PPR pulp to peel ratio and TSS total soluble solids.

The physical quality characteristics of the cooking type banana varieties (Cardaba, Nijiru, Matoke and Kitawira) are presented in Table 4. The fruit weight ranges from $178 \mathrm{~g}$ (Cardaba) to $69 \mathrm{~g}$ (Nijeru) were reported, while the variety had a significant $(\mathrm{P} \leq 0.001)$ effect on most of the fruit physical quality parameters (Table 4). However, no significant $(\mathrm{P} \geq 0.05)$ difference was observed between the fruit sample total soluble solids. Out of the four cooking banana varieties considered in this study Cardaba had shown the best performance for most physical quality parameters. The Cardaba variety had the highest mean fruit weight and volume. These might have contributed to the higher fruit weight as well as the unusual shape observed in Cardaba fruit as compared to that of Nijiru and Kitawira varieties. The Cardaba and Matoke had higher values, for fruit weight and length while Nijiru and Kitawira showed lower values than the reported average fruit weight and length values for the 
multi-location trial. The higher values obtained for Cardaba and Matoke could be explained by suitable agro-ecological conditions for better performance of the two varieties compared to the Kitawira and Nijiru varieties. The total soluble solids result was showed no significant $(\mathrm{P} \geq 0.05)$ varietal differences in terms of TSS. The TSS content was slightly affected by the genetic factor which was found to be $1.5 \%$ and $1.7 \%$ for Nijiru and Cardaba, respectively (Table 4 ) This clearly confirms that the sample fruit of the four varieties that were used for the postharvest characterization and evaluation of chips and boiling quality was at the required maturity stage.

The results of the proximate composition are summarized in Table 5. The cooking banana varieties had no significant $(\mathrm{P}>0.05)$ effect on fruit pulp $\mathrm{pH}$ values. According to Dadzie (1998), the high $\mathrm{pH}$ level in Cardaba variety presented in Table 5 corresponded banana fruit at a matured green stage. The TA value of Matoke was significantly higher $(\mathrm{P}<0.05)$ than that of Nijiru, Kitawira and Cardaba varieties (Table 5). This indicates that Matoke contains the highest amount of malic acid in its pulp. The TTA values also coincided with the results from the same author who reported malic acid contents ranging from $1.5 \%$ to $2.5 \%$ at harvest time for cooking banana. This could be used as an indicator of the maturity of a banana [16]. The Cardaba variety, had the highest fruit physical properties, had a significantly $(\mathrm{P} \leq 0.05)$ higher dry matter content as compared to the other varieties (Table 5). The dry matter result matches with Ferris et al. (1999) [27] who reported 30.4\% for Cardaba. Matoke, Nijiru, and Kitawira agree with values reported, Agunbiade et al. (2006) [28]. The moisture content was ranged from $7.89 \%$ to $9.61 \%$ in cooking banana. An increase in the moisture content during ripening might be due to carbohydrate breakdown, softening the tissue texture and osmotic transfer from the peel to pulp [28]. The moisture content was determined on the cooking banana samples. It is clear from the table of results that the two cooking banana varieties Kitawira and Nijeru varieties have higher moisture content than the cooking banana varieties. Comparing the four cooking varieties to the Matoka, the results showed that the Matoka had the lowest moisture content. The moisture contents of the varieties studied were significantly different. The moisture contents of the samples which are inversely related to its dry matter have been shown to be a useful quality-screening attribute. The selection of new progeny based on dry matter content provides an efficient way of eliminating materials with low-quality fruit (Ferris et al. 1996) [27]. It has also been reported that dry matter decreases with maturation (Trease and Evans 1989) [29]. This increase is due to carbohydrate utilization during maturation and osmotic transfer of water from the peel to the pulp.

Table 5. Proximate composition characteristics of cooking banana varieties.

\begin{tabular}{|c|c|c|c|c|c|c|c|c|c|}
\hline Varties & PH & $\mathbf{T A}$ & DM & Ash & Mo & CP & CF & CFt & Carb \\
\hline Cardaba & $6.1 \mathrm{a}$ & $1.8 \mathrm{~b}$ & $29 a$ & $2.00 \mathrm{a}$ & $8.11 \mathrm{~b}$ & $0.99 \mathrm{~b}$ & $2.71 \mathrm{a}$ & $1.04 \mathrm{a}$ & $85.15 \mathrm{a}$ \\
\hline Kitawira & $5.9 \mathrm{a}$ & $2.1 \mathrm{~b}$ & $19 b$ & $1.69 \mathrm{~b}$ & $9.61 \mathrm{a}$ & $0.93 b$ & $2.13 \mathrm{ab}$ & $1.11 \mathrm{a}$ & $84.53 a$ \\
\hline Matoka & $5.9 \mathrm{a}$ & $2.9 \mathrm{a}$ & $22 b$ & $1.32 \mathrm{c}$ & $7.89 \mathrm{~b}$ & $1.40 \mathrm{a}$ & $2.67 \mathrm{a}$ & $1.24 \mathrm{a}$ & $85.48 \mathrm{a}$ \\
\hline Nijeru & $5.9 \mathrm{a}$ & $2.0 \mathrm{~b}$ & $20 \mathrm{~b}$ & $1.60 \mathrm{~b}$ & $9.33 \mathrm{a}$ & $0.91 \mathrm{~b}$ & $2.93 a$ & $1.07 \mathrm{a}$ & $84.16 a$ \\
\hline Mean & 5.95 & 2.20 & 22.50 & 1.65 & 8.74 & 1.06 & 2.61 & 1.12 & $84.83 a$ \\
\hline $\mathrm{CV}$ & 1.97 & 4.51 & 6,72 & 4.21 & 3.77 & 1.89 & 2.00 & 2.14 & 1.11 \\
\hline Significance & ns & $*$ & $*$ & $* *$ & $* *$ & $*$ & ns & ns & ns \\
\hline
\end{tabular}

$\mathrm{ns}, * * *, * * *$ non-significant or significant at $\mathrm{P} \leq 0.05, \mathrm{P} \leq 0.01$ or 0.001 , respectively; means with the same letter within columns were not significantly different at $\mathrm{P} \leq 0.05$.

TA titrable acidity; DM dry matter; MO moisture; CP crude protein; $\mathrm{CF}$ crude fiber; $\mathrm{CFt}$ crude fate and Carb carbohydrate

The ash content in the samples was shown a significant effect oncomparing the released cooking banana. There were varied changes in the mineral composition of bananas during ripening and the ash content increased with ripening [30]. Khawas et al. [25] reported that ash content of banana fruits shows variations, which may be due to the differential absorption capacity of minerals at different stages of fruit development. The protein content shows that a significant difference among the varieties $0.91-1.40 \%$ cooking banana fruits. The protein content of banana fruit varied depending upon genome type, variety, altitude and climatic conditions [25]. The fat contents of the cooking banana samples were generally low. Crude fat contents of the cooking banana
Matoka had higher and Cardaba had low was 1.24 and 1.04\% respectively. These values are lower than those reported by earlier (Giami and Alu 1993). The difference in the crude fat content of the cooking banana. Banana's with low lipid and high energy contents make them very useful for the manufacturing of low fat diet formulations [31]. The crude fiber content was showed between cooking banana fruits 2.13 $-2.93 \mathrm{~g} / 100 \mathrm{~g}$. The food value of crude fiber is greater, which helps to regulate certain physiological functions. The highest crude fiber content was observed in Nijeru variety $(2.93$ $\mathrm{g} / 100 \mathrm{~g})$. The low fiber level of banana can be used for fortifying the weaning food. However, those fruits with high fiber content are desirable in adult diet, which is known to aid digestion, prevent constipation, help to the excretion of wastes and toxins from the body and also prevent colon cancer [32]. 


\subsection{Mineral Composition}

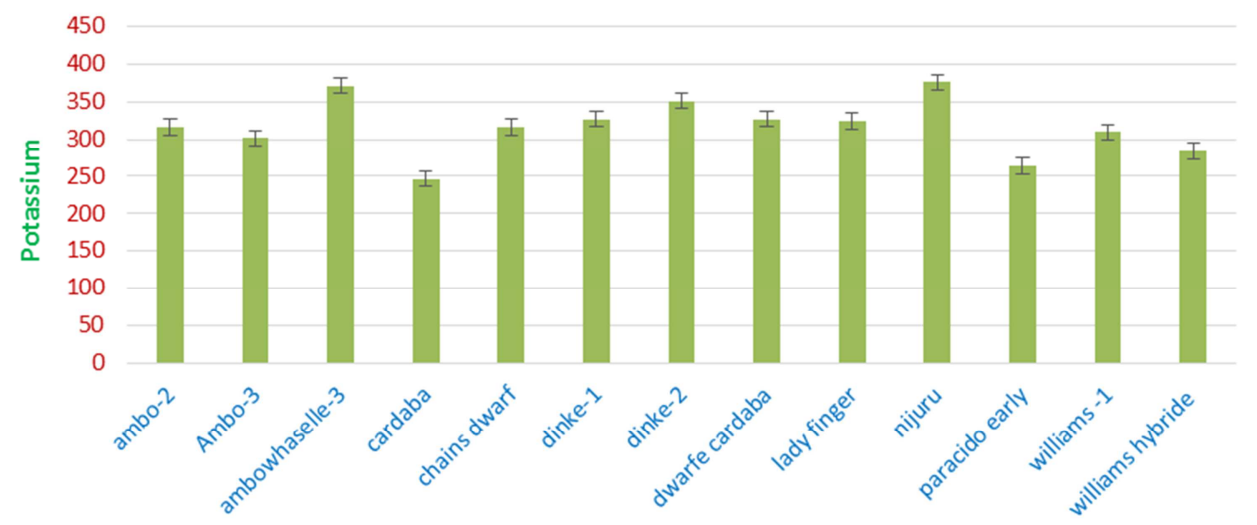

Varieties
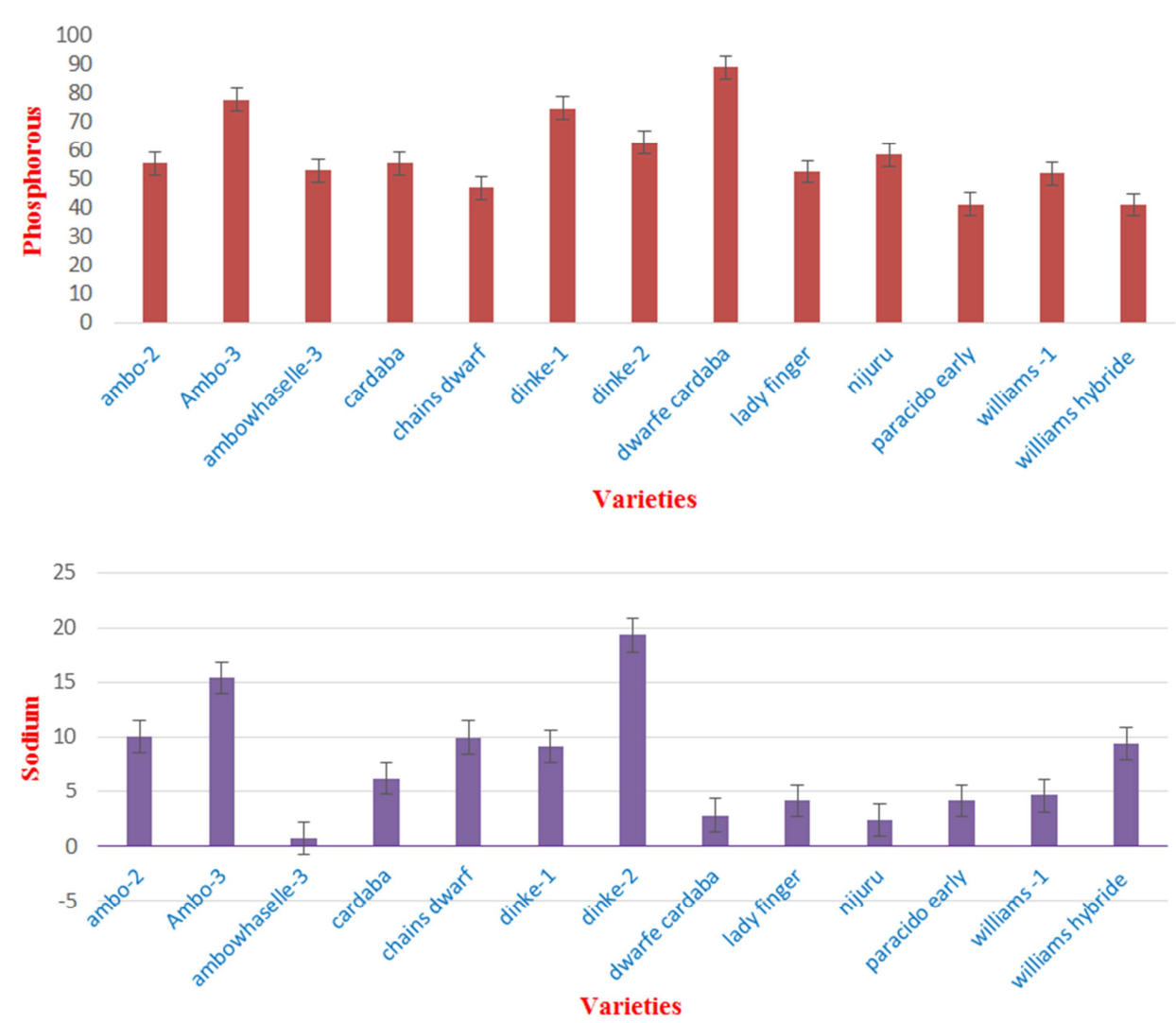

Figure 1. Shows the potassium, phosphorus and sodium contents of banana samples.

Banana contains rich sources of mineral nutrients and it could serve as a mineral element supplement in diet for both humans and animals [33]. Mineral nutrients such as potassium, phosphorus and sodium content of the banana samples are given in Figure 1 The observed value of potassium $(\mathrm{mg} / 100 \mathrm{~g})$ in banana samples was ranged from 375.95 to $246.29 \mathrm{mg} / 100 \mathrm{~g}$. The phosphorus $(\mathrm{mg} / 100 \mathrm{~g})$ content of the analyzed banana samples were obtained between the ranges of 89.13 to $41.20 \mathrm{mg} / 100 \mathrm{~g}$. The sodium content of banana samples observed in the range of 19.35 to $0.71 \mathrm{mg} / 100 \mathrm{~g}$. The potassium, phosphorus and sodium contents of banana sample varied from one variety to another variety these differences may be genetical differences between the varieties [34].

\subsection{Sensory Quality Evaluation}

For comprehensive new variety evaluation, assessing the utilization aspects is very crucial. Hence, in this study, to complement the physical and chemical postharvest characterization of green matured fruit of some desert-type banana varieties, sensory evaluation had been considered. Table 6 shows fruit sensory quality of some desert banana varieties. 
Table 6. Sensory quality of fresh fruit from desert type banana varieties.

\begin{tabular}{|c|c|c|c|c|c|c|}
\hline Varieties & Color & Peeling conditions & Texture & Taste & Oder & Overall acceptability \\
\hline Ambo-2 & $4.167^{\mathrm{a}}$ & $4.006^{\mathrm{ab}}$ & $4.199^{\mathrm{a}}$ & $3.917^{\mathrm{abc}}$ & $4.2117^{\mathrm{a}}$ & $4.2500^{\mathrm{ab}}$ \\
\hline Dinka-2 & $4.097^{\mathrm{a}}$ & $4.285^{\mathrm{a}}$ & $4.063^{\mathrm{a}}$ & $3.667^{\mathrm{bcd}}$ & $3.8753^{\mathrm{a}}$ & $4.0140^{\mathrm{abc}}$ \\
\hline Lady finge & $4.069^{\mathrm{a}}$ & $4.208^{\mathrm{a}}$ & $4.110^{\mathrm{a}}$ & $4.214^{\mathrm{a}}$ & $4.2380^{\mathrm{a}}$ & $4.3840^{\mathrm{a}}$ \\
\hline Paracido aerly & $3.767^{\mathrm{a}}$ & $3.513^{\mathrm{b}}$ & $3.942^{\mathrm{ab}}$ & $4.042^{\mathrm{ab}}$ & $3.8253^{\mathrm{a}}$ & $3.9573^{\mathrm{abc}}$ \\
\hline Williams h & $3.746^{\mathrm{a}}$ & $3.696^{\mathrm{ab}}$ & $3.750^{\mathrm{ab}}$ & $3.492^{\text {cd }}$ & $4.0877^{\mathrm{a}}$ & $3.9293^{\mathrm{abc}}$ \\
\hline Chinese dw & $3.722^{\mathrm{a}}$ & $3.366^{\mathrm{b}}$ & $3.2897^{\mathrm{b}}$ & $3.345^{\mathrm{d}}$ & $3.6353^{\mathrm{a}}$ & $3.5657^{\mathrm{c}}$ \\
\hline ambo-3 & $3.708^{\mathrm{a}}$ & $3.750^{\mathrm{ab}}$ & $3.750^{\mathrm{ab}}$ & $3.833^{\mathrm{abcd}}$ & $3.5833^{\mathrm{a}}$ & $3.7083^{\mathrm{bc}}$ \\
\hline LSD & 0.5956 & 0.6547 & 0.7282 & 0.5352 & 0.8079 & 0.5565 \\
\hline $\mathrm{CV}$ & 8.99 & 10.02 & 10.99 & 8.27 & 12.13 & 8.24 \\
\hline Significance & ns & ns & ns & ns & ns & ns \\
\hline F-calcu & 0.90 & 1.92 & 1.26 & 2.42 & 0.82 & 1.86 \\
\hline
\end{tabular}

Each observation is a mean $(\mathrm{n}=21)$. ${ }^{*}{ }^{*}$ significant at $\mathrm{P} \leq 0.05$ or $\mathrm{P} \leq 0.01$, respectively. Means with the same letter within columns were not significantly different at $\mathrm{P} \leq 0.05$.

The color of the fresh banana fruit is important in the assessment of consumer acceptability. In the sensory studies, the panelists indicated that there were no significant difference color variations among the evaluated fresh fruit samples. This result clearly indicated that screening of new varieties only with physicochemical properties could not be complete without sensory evaluation and that it finally proves consumer acceptance. There were no significant differences $(\mathrm{P}>0.05)$ among the desert banana varieties in their fruit fresh texture (Table 6). The panellists' score indicated that the fresh desert type banana fruit had very hard to good texture. Willbur and Shairi (1985) reported that specific gravity has a direct relationship to the processing efficiency, texture, and yield of different products. [13] Hence, similarity in fresh fruit texture score among the varieties could be explained by the no significant difference in specific gravity and firmness of fruit used for fresh banana fruit (Table 6). The sensory panel also did not detect significant differences $(\mathrm{P}>0.05)$ among varieties in the fresh fruit taste (Table 6). Taste is mainly a balance between the sugar and acid contents (Dadzie and Orchard 1997) [35]. Thus, lack of significant difference in fresh fruit tastes sensory quality can be linked to the similarity in the TSS and $\mathrm{pH}$ of the varieties tested. The group of consumers' panelists could be taken as good responsibilities for the market potential of desert banana fresh fruit. This indicates that these varieties could produce acceptable for different fruit processing products and fresh fruit regarding their taste. According to the hedonic scoring scale, panelists indicated that the fresh fruit from the different desert type banana varieties had good to very good overall acceptability scores. In other words, although colour of chips contributed to the overall acceptability of the evaluated fresh fruit colour, taste and texture were the most influential factors for consumers processed and fresh quality in the overall quality acceptance. Generally, panelists' scores for overall acceptance for desert banana fresh fruits ranged from good to very good scale. This indicates that consumers may not reject desert fresh banana fruits though they are accustomed to other fresh fruits.

\section{Conclusion}

The results indicated that the desert banana type has been showed the highly significant between varieties and Cardaba had superior values for physical characteristics. Nijiru and Kitawira had the smallest, shortest, thinnest fruit and the edible portions mass almost equal to peel mass. Cardaba had a higher proportion of pulp per unit mass. In terms of green matured fruit, the chemical quality was found to be significant amongst the tested varieties. The physicochemical quality of desert and pipeline banana trial varieties were showed highly significantly. The good cooking qualities of Cardaba could be related to its comparatively ease of peel, lower water absorption potential, slightly higher pulp firmness before cooking, higher percentage of pulp dry matter content and pulp to peel ratio. Nijiru, Kitawira, and Matoke were relatively watery and produced a softer pulp on cooking, indicating their lower suitability for boiling purposes. The sensory analysis of desert banana quality of fresh fruit pulp was showed there was no significant difference between varieties. The panelist acceptance score, preference percentage, objective fresh quality, and profitability evaluation indicates that the desert type of bananas was acceptable for fresh consumption and Nijiru, Kitawira and Matoke possess better potential for producing a comparably acceptable quality of processed products than the Cardaba variety. The outcome of this research will help the food industry to optimize the nutritional compositions while designing new products that utilize the banana varieties discussed in the paper.

\section{Acknowledgements}

Financial support received from the department of food science and nutrition research directorate, EIAR is gratefully acknowledged. The authors are grateful to Melkassa Agricultural research center, food science and horticulture researchers for their help.

The authors declare no conflicts of interest regarding the 
publication of this paper.

\section{References}

[1] Robinson, J. C. and V. G. Saúco, Bananas and plantains. Vol. 19. 2010: Cabi.

[2] Onwuka, G., A. Onyemachi, and N. David-Chukwu, Comparative evaluation of proximate composition and functional properties of two varieties of cooking banana. IOSR Journal of Environmental Science, Toxicology and Food Technology, 2015. 9 (1): p. 01-04.

[3] Pereira, A. and M. Maraschin, Banana (Musa spp) from peel to pulp: ethnopharmacology, source of bioactive compounds and its relevance for human health. Journal of ethnopharmacology, 2015. 160: p. 149-163.

[4] Carvalho, F. P., Agriculture, pesticides, food security and food safety. Environmental science \& policy, 2006.9 (7-8): p. 685692.

[5] Stover, R., Somaclonal variation in Grand Naine and Saba bananas in the nursery and field. Banana and plantain breeding strategies, 1987. 21: p. 136-139.

[6] Tefera, T., et al., Parasitic contamination of fruits and vegetables collected from selected local markets of Jimma Town, Southwest Ethiopia. International scholarly research notices, 2014. 2014.

[7] Shamebo, D., Banana in the southern region of Ethiopia (SRE). Bananas and Food Security, 1998. 119.

[8] Saifullah, R., et al., Utilization of green banana flour as a functional ingredient in yellow noodle. International Food Research Journal, 2009. 16 (3): p. 373-379.

[9] Adeniji, T. A., Plantain, banana and wheat flour composites in bread making: prospects for industrial application. African Journal of Food, Agriculture, Nutrition and Development, 2015. 15 (4): p. 10182-10197.

[10] Narayana, C. K. and M. Pillay, 14 Postharvest Processed Products from Banana. Banana Breeding: Progress and Challenges, 2011: p. 269.

[11] Wishart, D. S., Metabolomics: applications to food science and nutrition research. Trends in food science \& technology, 2008. 19 (9): p. 482-493.

[12] Sun - Waterhouse, D., The development of fruit - based functional foods targeting the health and wellness market: $a$ review. International Journal of Food Science \& Technology, 2011. 46 (5): p. 899-920.

[13] Belayneh, M., T. Workneh, and D. Belew, Physicochemical and sensory evaluation of some cooking banana (Musa spp.) for boiling and frying process. Journal of food science and technology, 2014. 51 (12): p. 3635-3646.

[14] Berhe, K., et al., Innovation in banana value chain development in Metema district, northwestern Ethiopia: IPMS experiences. 2008.

[15] Waghmare, S. and R. Chavan, Some quantitative studies of carbohydrate metabolites in cestode parasite of Gallus gallus domesticus. International Journal of Parasitology Research, 2010. 2 (1): p. 1.
[16] Dadzie, B. K. and J. E. Orchard, Routine post-harvest screening of banana/plantain hybrids: criteria and methods. Vol. 2. 1997: Bioversity International.

[17] Bugaud, C., et al., Physicochemical analysis of mountain bananas from the French West Indies. Scientia Horticulturae, 2006. 108 (2): p. 167-172.

[18] Tigist, M., T. S. Workneh, and K. Woldetsadik, Effects of variety on the quality of tomato stored under ambient conditions. Journal of food science and technology, 2013. 50 (3): p. 477-486.

[19] Adi, D. D., I. N. Oduro, and C. Tortoe, Physicochemical changes in plantain during normal storage ripening. Scientific African, 2019. 6: p. e00164.

[20] Vermeir, S., et al., Instrumental based flavour characterisation of banana fruit. LWT-Food Science and Technology, 2009. 42 (10): p. 1647-1653.

[21] Jackson, T. and N. Badrie, Quality Changes on Storage of Caribbean Banana (Musa acuminata) Wines: Effects of Pectolase Concentration and Incubation Period. Journal of Wine Research, 2002. 13 (1): p. 43-56.

[22] Latef, A. A. H. A. and H. Chaoxing, Effect of arbuscular mycorrhizal fungi on growth, mineral nutrition, antioxidant enzymes activity and fruit yield of tomato grown under salinity stress. Scientia Horticulturae, 2011. 127 (3): p. 228-233.

[23] Lima, J. L., A. O. Rangel, and M. R. S. Souto, Simultaneous determination of potassium and sodium in vegetables by flame emission spectrometry using a flow-injection system with two dialysis units. Analytical sciences, 1996. 12 (1): p. 81-85.

[24] Ballentine, R. and D. D. Burford, [148] Determination of metals (Na, K, Mg, Ca, Mn, Fe, Co, Cu, Zn). 1957.

[25] Kookal, S. K. and A. Thimmaiah, Nutritional Composition of Staple Food Bananas of Three Cultivars in India. American Journal of Plant Sciences, 2018. 9 (12): p. 2480-2493.

[26] Tapre, A. and R. Jain, Study of advanced maturity stages of banana. International Journal of Advanced Engineering Research and Studies, 2012. 1 (3): p. 272-274.

[27] Ferris, R. S. B., R. Ortiz, and D. Vuylsteke, Fruit quality evaluation of plantains, plantain hybrids, and cooking bananas. Postharvest biology and technology, 1999. 15 (1): p. 73-81.

[28] Agunbiade, S., J. Olanlokun, and O. Olaofe, Quality of chips produced from rehydrated dehydrated plantain and banana. Pakistan Journal of Nutrition, 2006. 5 (5): p. 471-473.

[29] Emaga, T. H., et al., Effects of the stage of maturation and varieties on the chemical composition of banana and plantain peels. Food chemistry, 2007. 103 (2): p. 590-600.

[30] Adeyemi, O. and A. Oladiji, Compositional changes in banana (Musa ssp.) fruits during ripening. African Journal of Biotechnology, 2009. 8 (5).

[31] Giami, S. Y. and D. A. Alu, Changes in composition and certain functional properties of ripening plantain (Musa spp., AAB group) pulp. Food chemistry, 1994. 50 (2): p. 137-140.

[32] Gharibzahedi, S. M. T. and S. M. Jafari, The importance of minerals in human nutrition: Bioavailability, food fortification, processing effects and nanoencapsulation. Trends in Food Science \& Technology, 2017. 62: p. 119-132. 
[33] Soetan, K., C. Olaiya, and O. Oyewole, The importance of mineral elements for humans, domestic animals and plants- $A$ review. African journal of food science, 2010. 4 (5): p. 200222.

[34] Gibson, R. S., et al., A review of phytate, iron, zinc, and calcium concentrations in plant-based complementary foods used in low-income countries and implications for bioavailability. Food and nutrition bulletin, 2010. 31 (2_suppl2): p. S134-S146.

[35] Hailu, M., T. Workneh, and D. Belew, Effect of packaging materials on the quality of banana cultivars. African Journal of Agricultural Research, 2012.7 (7): p. 1226-1237. 